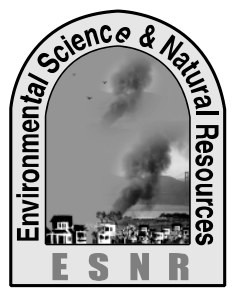

\title{
Effects of Water Quality Parameters on Abundance and Biomass of Zooplankton in Merbok Estuary Malaysia
}

\author{
K. Fatema ${ }^{1 *}$, W. M. W. Omar' ${ }^{2}$, M. M. Isa ${ }^{2}$ and A. Omar ${ }^{3}$ \\ ${ }^{1}$ Department of Fisheries, \\ University of Dhaka, Dhaka - 1000, Bangladesh \\ ${ }^{2}$ School of Biological Sciences, \\ Universiti Sains Malaysia, 11800 Penang, Malaysia \\ ${ }^{3}$ Center for Marine and Coastal Studies (CEMACS), \\ Universiti Sains Malaysia, 11800 Penang, Malaysia \\ *Corresponding author: f.kaniz@yahoo.com
}

\begin{abstract}
Influence of water quality parameters on zooplankton abundance and biomass in the Merbok estuary Malaysia were investigated. Twenty four hours sampling were conducted at station 1,3 and 5 from $12^{\text {th }}$ November (spring tide) to $3^{\text {rd }}$ December (neap tide) 2011 on weekly interval. Results showed that water quality parameters varied with the following ranges: conductivity $(10.00-315.00 \mu \mathrm{S}$ $\left.{ }^{1} \mathrm{~cm}\right)$, transparency $(25.50-154.00 \mathrm{~cm})$, light intensity $(53.5-1959.00 \mathrm{lux})$, TSS $\left(20-70 \mathrm{mg}^{-1} \mathrm{~L}\right)$, BOD $\left(0.25-3.46 \mathrm{mg}^{-1} \mathrm{~L}\right)$ and chl $a(0.1-$ $\left.1.46 \mu \mathrm{g}^{-1} \mathrm{~L}\right)$. The highest zooplankton abundance was found at Station $5\left(176 \times 10^{3}\right)$ and $\left(230 \times 10^{3}\right) \mathrm{ind}^{-3} \mathrm{~m}$ and the lowest was at station $1\left(5.3 \times 10^{3}\right)$ and $\left(3.4 \times 10^{3}\right)$ ind $^{-3} \mathrm{~m}$ during spring and neap tide. Zooplankton biomass varied from 0.04 to $0.096 \mathrm{gm}^{-3} \mathrm{~m}$. Spearman's rank correlation analysis results showed that there was a correlation among zooplankton abundance and conductivity, transparency, TSS, BOD, and biomass except chl and light intensity. Mann-Whitney U test result showed that water quality parameters, zooplankton abundance and zooplankton biomass were significantly different between spring and neap tides.
\end{abstract}

Key words: Estuary, Water quality parameters, Zooplankton abundance

\section{Introduction}

Water bodies such as lakes, rivers, ponds, and estuaries are water sources for domestic, industrial, agriculture and aquaculture. Zooplankton plays important roles in estuarine ecosystems and they are an important food for a variety of estuarine consumers including ctenophores, meroplanktonic larvae, a number of forage fish and some benthic organisms such as sponges and molluscs (Reeve, 1975). Water quality parameters may affect the distribution of estuarine zooplankton (Vecchionne, 1989). The density and diversity of zooplankton are controlled by several physico-chemical factors (Bais and Agarwal, 1995). Tides have a major influence on the structure and density of these communities (Robertson et al., 1988). Variations in zooplankton composition and abundance have been correlated to spring/neap tide alterations (Krumme and Liang, 2004; da Costa et al., 2011; Davies and Ugwumba, 2013). Therefore, this study was undertaken to know the complex effects of water quality parameters and tides on zooplankton abundance and biomass in Merbok estuary.

\section{Materials and Methods}

Zooplankton and water samples were made during the time period of 4 weeks $\left(12^{\text {th }}\right.$ November to $3^{\text {rd }}$ December 2011). There were four samplings in each week. The samplings were made with six hours of interval. Station 1(St 1) (upstream), station 3(St 3) (middle stream) and station 5 (St 5) (downstream) were selected for this study. Water samples were collected by acid washed polythene bottles (1.5 liter) from each station (three replicates) for laboratory analysis. All the water samples were kept in the dark and cool temperature $\left(4^{\circ} \mathrm{C}\right)$ in the cool box before transporting to the laboratory. Then the collected samples were kept in a refrigerator at a temperature below $4{ }^{\circ} \mathrm{C}$. Electrical conductivity was measured with Hydrolab Surveyor 3 Data Logger (Model no\# SVR3-DL, USA). Water transparency was observed with a Secchi disk $20 \mathrm{~cm}$ in diameters (Wetzel and Likens, 2000). Datalogging light meter (RS-232) was used to measure light intensity of the environment. Biochemical Oxygen Demand (BOD) and Total Suspended Solids (TSS) were determined according to APHA (1991). Chlorophyll $a$ was measured by the using the Strickland and Parsons (1972) method.

Zooplankton samples were taken from a few centimeter from the surface water by horizontal towing of plankton net $(0.13 \mathrm{~m}$ in diameter), made up of bolting silk (mesh size $150 \mu \mathrm{m}$ ) for 18 minutes. Three tows were made for each sampling station. For each tow, the filtered water volume $\left(\mathrm{m}^{3}\right)$ was measured using mouth area of the net and distance of towing. Then zooplankton samples were collected from the cod end by washing and dipping the net up and down in the sample water without submerging the mouth as a quick rinse down against current. Samples were immediately preserved in $4 \%$ buffered formalin.

Formula used for calculation of filtered water volume is given below: $\mathrm{V}=\pi \mathrm{r}^{2} \mathrm{~L}$ where, $\mathrm{V}=$ volume of water towed, $\mathrm{r}=$ radius of plankton net, $\mathrm{L}=$ distance of towing. Density of the zooplankton from the subsample was standardized into the number of individuals per cubic meter (ind ${ }^{-3} \mathrm{~m}$ ) according to the following formula (Postel et al. 2000): $\mathrm{N}=\mathrm{n} \mathrm{S} / \mathrm{w}$ where, $\mathrm{N}=$ density of individual $\left(\right.$ ind $\left.^{-3} \mathrm{~m}\right), \mathrm{n}=$ the number of individuals in the sub-sample, $\mathrm{S}=$ the fraction of the subsample, $\mathrm{w}=$ volume of water filtered $\left(\mathrm{m}^{3}\right)$. 
Nonparametric analysis (Kruskal-Wallis $\mathrm{H}$ test) was used to show significant differences among sampling stations. Significant differences of zooplankton density and water quality parameters between spring and neap tide were determined using the Mann-Whitney U test. Spearman's rank correlation were performed to find the relationship between zooplankton abundance and water quality parameters (Ho, 2006).

\section{Results and Discussion}

\section{Conductivity}

Conductivity values varied from $10.00-315.00 \mu \mathrm{S}^{-1} \mathrm{~cm}$ during spring tide with the mean value of $198.81 \pm$ $106.84 \mu \mathrm{S}^{-1} \mathrm{~cm}$ while during neap tide the mean value of conductivity was $161.06 \pm 71.48 \mu \mathrm{S} / \mathrm{cm}$ with the range of 21.00-263.00 $\mu^{-1} \mathrm{~cm}$ (Fig. 1). The maximum conductivity $\left(315.00 \mu \mathrm{S}^{-1} \mathrm{~cm}\right)$ was found at station 5 (high tide) and the lowest $\left(10.00 \mu \mathrm{S}^{-1} \mathrm{~cm}\right)$ were at station 1 (low tide). Conductivity was significantly different between stations (Kruskal Wallis $\mathrm{H}$ test, $\mathrm{p}<0.01$ ) and between spring and neap tide (MannWhitney $\mathrm{U}$ test, $\mathrm{p}<0.01)$.

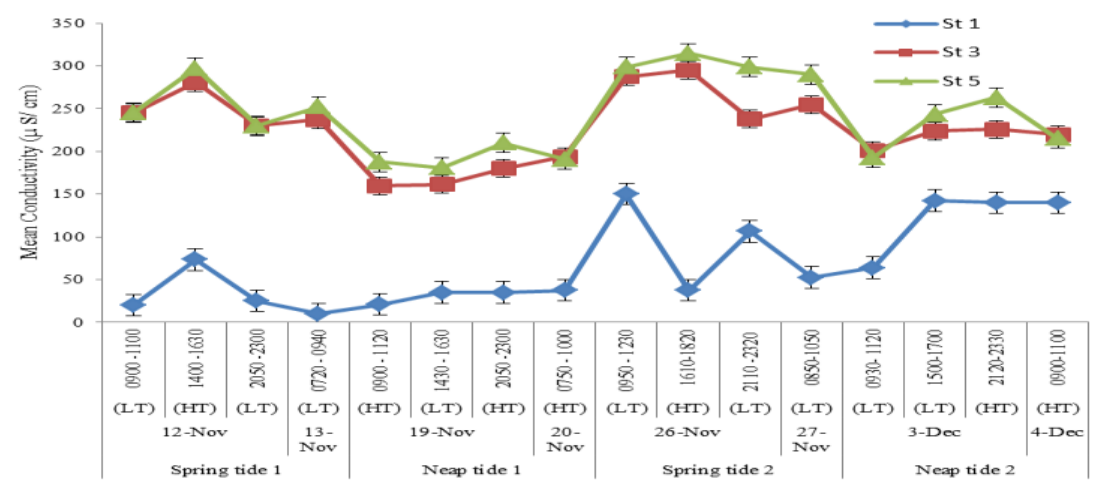

Fig. 1. Mean conductivity of Merbok River estuary at different sampling stations during 24 hour observation

During spring tide conductivity level was higher compared with neap tide among the stations. The highest concentration of conductivity was found in down-stream. This may be due to higher salinity resulting higher ionic concentration. Tebbutt (1998) reported that conductivity is generally affected by Total Dissolved Solids (TDS) and a higher ionic content in the water showed a higher ability of water to conduct electricity. tide while during neap tide the mean value was 102.17 $\pm 39.38 \mathrm{~cm}$ with the range of $25.50-154.00 \mathrm{~cm}$ (Fig. 2). The maximum $(154.00 \mathrm{~cm})$ was recorded at station 3 (high tide) and the minimum $(25.50 \mathrm{~cm})$ at Station 1 (low tide). Kruskal Wallis $\mathrm{H}$ test showed that transparency was significantly different between stations $(\mathrm{p}<0.01)$. Mann-Whitney $U$ test showed that transparency was significantly different between spring and neap tide $(\mathrm{p}<0.01)$.

\section{Transparency}

Transparency values varied from $29.00-126.50 \mathrm{~cm}$ with the mean value of $83.63 \pm 27.14 \mathrm{~cm}$ during spring

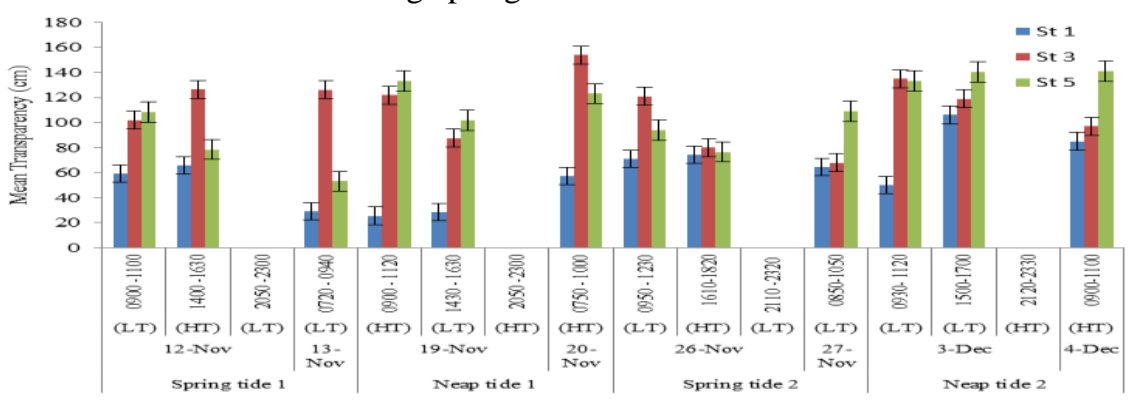

Fig. 2. Mean water transparency of Merbok River estuary at different sampling stations during 24 hour observation

The lowest transparency value was recorded in the upper zone (station 1) and the highest value in the middle stream. According to Reid (1961) transparency value in an estuary decrease from the upper reaches to the mouth of the basin. 
This is due to diminution in velocity and carrying capacity of the inflowing stream current, and to electrolytic effects of sea-water salts.

\section{Light intensity}

Light intensity values varied from 53.50-1836.00 lux with the mean value of $890.66 \pm 553.62$ lux during spring tide while during neap tide the mean value was $1062.77 \pm 561.46$ lux with the range of 228.00-1959.00 lux (Fig. 3). The maximum light intensity was found 1959.00 lux whereas; the minimum was 53.5 lux at station 5 at low tide. Kruskal Wallis $\mathrm{H}$ test showed that light intensity was insignificant between stations ( $>0.05)$. Mann-Whitney $U$ test showed that light intensity was significantly different between spring and neap tide $(\mathrm{p}<0.05)$.

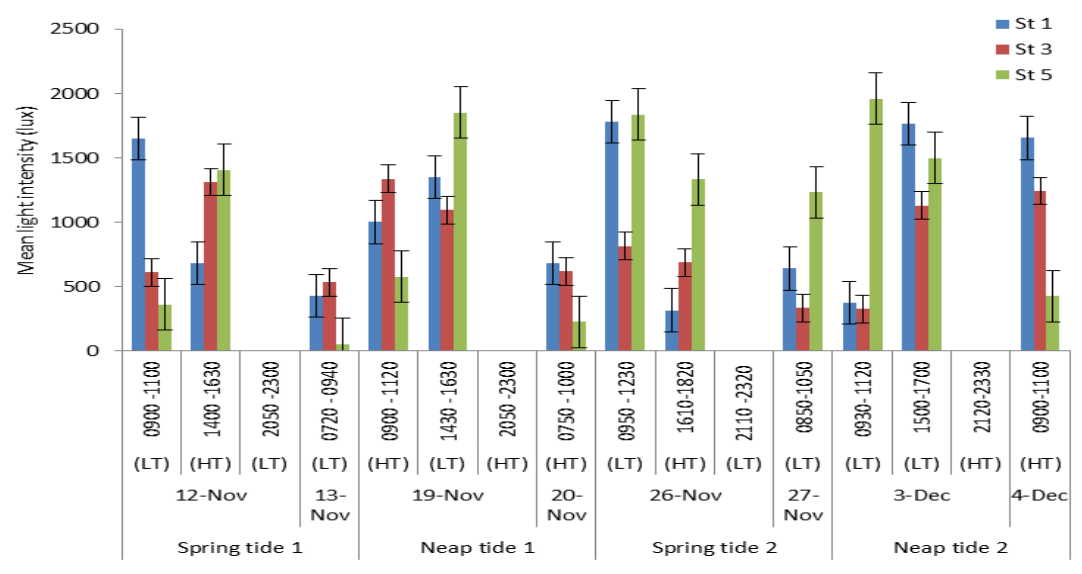

Fig. 3. Mean light intensity of Merbok River estuary at different sampling stations during 24 hour observation

\section{Total Suspended Solids (TSS)}

During spring tide TSS values varied from 20.00 $70.00 \mathrm{mg}^{-1} \mathrm{~L}$ with the mean value of $35.00 \pm 13.00 \mathrm{mg}^{-}$ ${ }^{1} \mathrm{~L}$ while during neap tide the mean value was $27.36 \pm$ $5.73 \mathrm{mg}^{-1} \mathrm{~L}$ with the range of $20-40.00 \mathrm{mg} / \mathrm{L}$ (Fig. 4). The lowest TSS $\left(20 \mathrm{mg}^{-1} \mathrm{~L}\right)$ was at Station 1 and 3 whereas, the highest $\left(70 \mathrm{mg}^{-1} \mathrm{~L}\right)$ was observed at Station 5. Kruskal Wallis $H$ test result showed that TSS was significantly different among stations $(\mathrm{p}<0.01)$. MannWhitney $U$ test showed that TSS was significantly different between spring and neap tide $(\mathrm{p}<0.01)$.

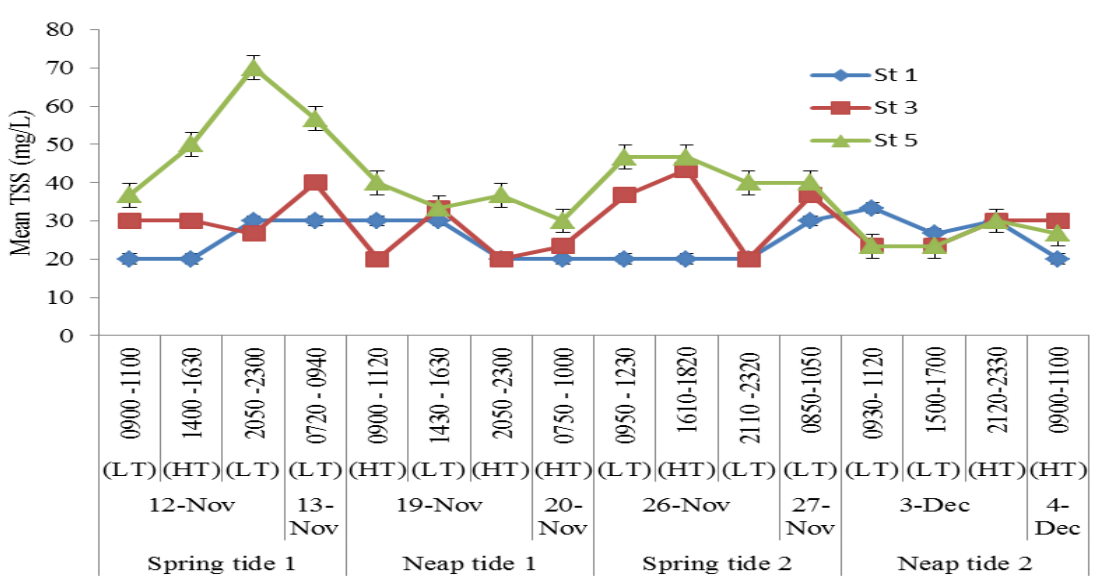

Fig. 4. TSS (mean \pm SE) of Merbok River estuary at different sampling stations during 24 hour observation

This study showed that the lowest TSS was observed at Station 1 and 3 during low tide whereas, the highest was found at Station 5 during low tide (Fig. 4). It may be due to run off from up and mid-stream. Zheng et al. (2003) reported that TSS concentrations varied over a tidal cycle and the highest at maximum flood and ebb tidal phases and lowest at slack tides.
Biological Oxygen Demand (BOD)

BOD values varied from $0.25-3.46 \mathrm{mg}^{-1} \mathrm{~L}$ with the mean value of $1.40 \pm 0.79 \mathrm{mg}^{-1} \mathrm{~L}$ during spring tide while during neap tide the mean value was $1.59 \pm 0.69$ $\mathrm{mg}^{-1} \mathrm{~L}$ with the range of $0.07-2.69 \mathrm{mg} / \mathrm{L}$ (Fig. 5). The maximum $\left(3.46 \mathrm{mg}^{-1} \mathrm{~L}\right)$ BOD was found at station 1 whereas, the minimum $\left(0.07 \mathrm{mg}^{-1} \mathrm{~L}\right)$ BOD in station 1 at low tide. Kruskal Wallis $\mathrm{H}$ test result showed that BOD 
was significantly different among stations $(\mathrm{p}<0.01)$. Mann-Whitney $U$ test result showed that BOD was significantly different between spring and neap tide $(\mathrm{p}<0.01)$.

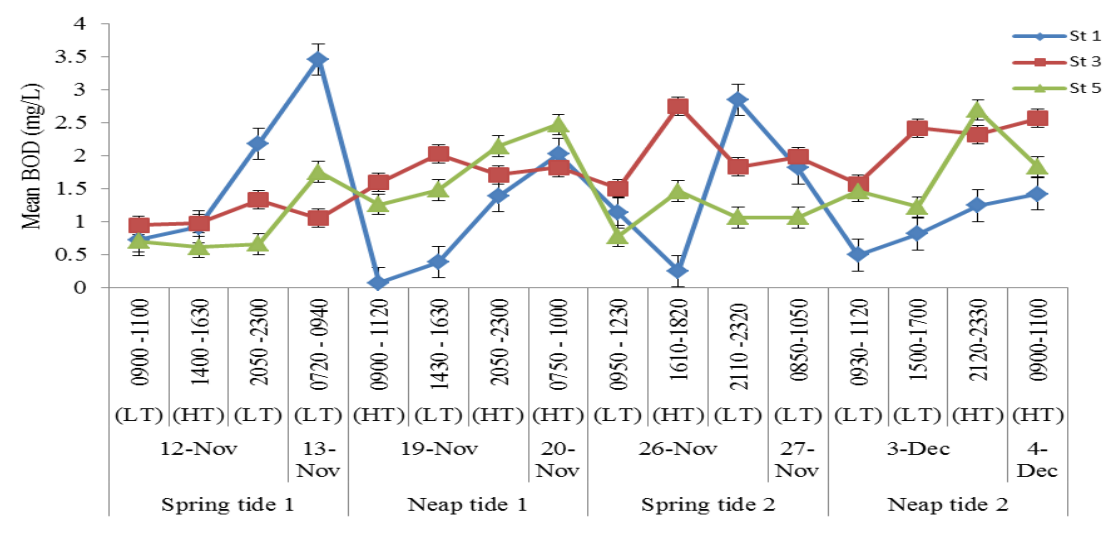

Fig. 5. Concentration of BOD (mean \pm SE) of Merbok River estuary at different sampling station during 24 hour observation

This present study found that BOD values are peak in spring tide compare with neap tide and significant higher BOD value was found at the upper zone of the river system at low tide. It may be due to upper runoff, which discharges into the estuary. Bernard (1975) reported that higher abundance of plankton organisms in the water samples apparently served as a source of organic media or was themselves consumers of oxygen which leading to higher BOD values at the sampling stations.

\section{Chlorophyll a}

The concentration of chlorophyll $a$ varied from 0.11 $0.561 \mu \mathrm{g}^{-1} \mathrm{~L}$ with the mean value of $0.39 \pm 0.11 \mu \mathrm{g}^{-1} \mathrm{~L}$ during spring tide while during neap tide the mean value was $0.60 \pm 0.32 \mu \mathrm{g}^{-1} \mathrm{~L}$ with the range of $0.1-1.46$ $\mu \mathrm{g}^{-1} \mathrm{~L}$ (Fig. 6). The maximum (1.46 $\mu \mathrm{g}^{-1} \mathrm{~L}$ ) chlorophyll $a$ was found at station 1 (high tide) and the minimum $\left(0.1 \mu \mathrm{g}^{-1} \mathrm{~L}\right)$ in station 1 (high tide). Kruskal Wallis $\mathrm{H}$ test result showed that chlorophyll $a$ was insignificant among stations ( $p>0.05$ ). Mann-Whitney U test result showed that chlorophyll $a$ was significantly different between spring and neap tide $(\mathrm{p}<0.01)$. This study result showed that peak concentration of chlorophyll $a$ was at station 1 and the lowest concentration was also the same station at high tide. It may be due to the flushing of nutrients and organic particles by runoff and presence of extensive mangrove vegetation. Sun et al.
(2011) found that phytoplankton community was induced by nutrients especially in the mangrove area where nutrient input was high.

\section{Zooplankton abundance}

Zooplankton abundance was higher during neap tide compared to spring tide (Fig. 7). During spring and neap tide, peak abundance was found at station 5 with the value of $176 \times 10^{3}$ and $230 \times 10^{3}$ ind $^{-3} \mathrm{~m}$ at high tide. Lower abundance was observed at station 1 with 5,339 and 3,455 ind $^{-3} \mathrm{~m}$ at low and high tide, respectively. Kruskal Wallis $\mathrm{H}$ test showed that zooplankton abundance were significantly different $(\mathrm{p}<0.05)$ among the stations. Mann-Whitney $U$ test found that zooplankton abundance were significant $(\mathrm{p}<0.05)$ between spring and neap tide.

\section{Zooplankton biomass}

During spring tide biomass varied from 0.04 (station 1) - 0.96 (station 5) $\mathrm{gm}^{-3} \mathrm{~m}^{3}$ whereas, it varied from 0.03 (station 1) - 0.81 (station 3 ) $\mathrm{gm}^{-3} \mathrm{~m}$ for neap tide. Higher biomass was recorded during high tide while lower biomass was evident during low tide (Fig. 8). Kruskal Wallis $\mathrm{H}$ test showed that zooplankton biomass were insignificant $(p>0.05)$ among the stations. MannWhitney $U$ test found that zooplankton biomass were significant $(\mathrm{p}<0.01)$ between spring and neap tide. 


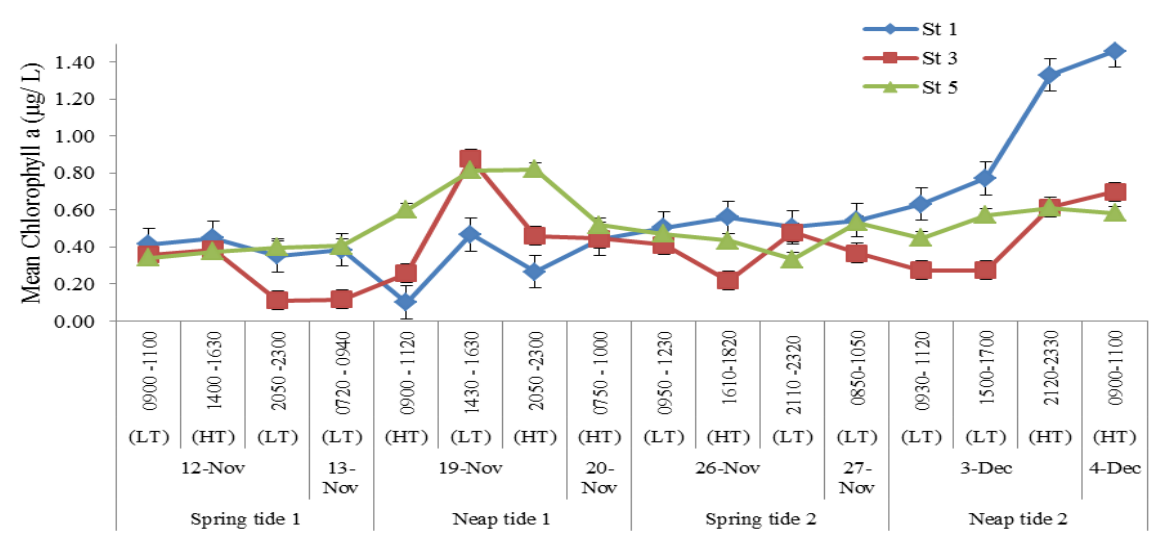

Fig. 6. The average concentration of chlorophyll $a$ (mean \pm SE) of Merbok River estuary at different sampling station during 24 hour observation

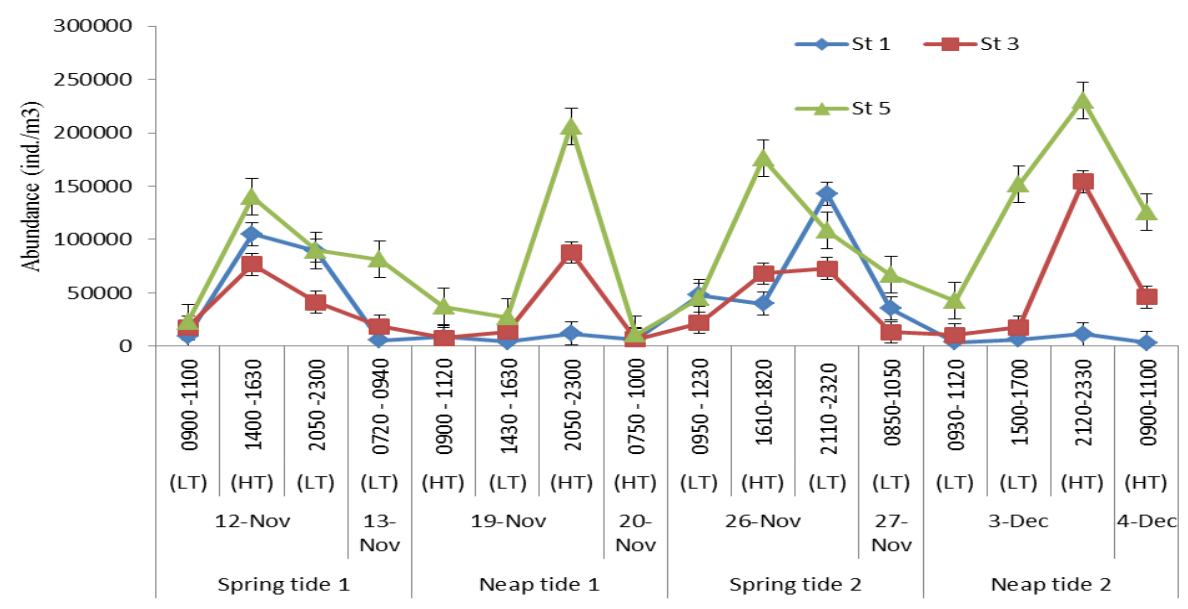

Fig. 7. Zooplankton abundance at all stations in Merbok River estuary during 24 - hour observation

Tidal cycles had significant effects on the zooplankton density. Tidal flushing is one of the main bottom-up factors controlling zooplankton biomass in estuaries (Villate, 1997; Ali et al. 2011). During 24 hour observation, peak and higher zooplankton abundance and biomass were found during high tide. This is may be due to upward movement of sea water. Robertson et al. (1988) studied in mangrove and other nearshore habitats in tropical Australia and Wang et al. (1995) studied in a megatidal estuary Seine, in eastern English Channel. Both studies also observed higher zooplankton abundance and biomass at high tide than that of low tide.

Results of Spearman's rank correlation analysis found that zooplankton abundance was positively correlated with conductivity $(\mathrm{r}=0.517 * *, \mathrm{p}<0.01)$, transparency $\left(\mathrm{r}=0.198^{*}, \mathrm{p}<0.05\right)$, TSS $\left(\mathrm{r}=0.247^{* *}, \mathrm{p}<0.01\right)$, BOD $(\mathrm{r}=0.310 * *, \mathrm{p}<0.01)$ and biomass $\left(\mathrm{r}=0.670^{* *}, \mathrm{p}<0.01\right)$. This may be due to tidal effects. No correlation was found with chlorophyll $a$ and light intensity. This couldbe due to diurnal variability. 


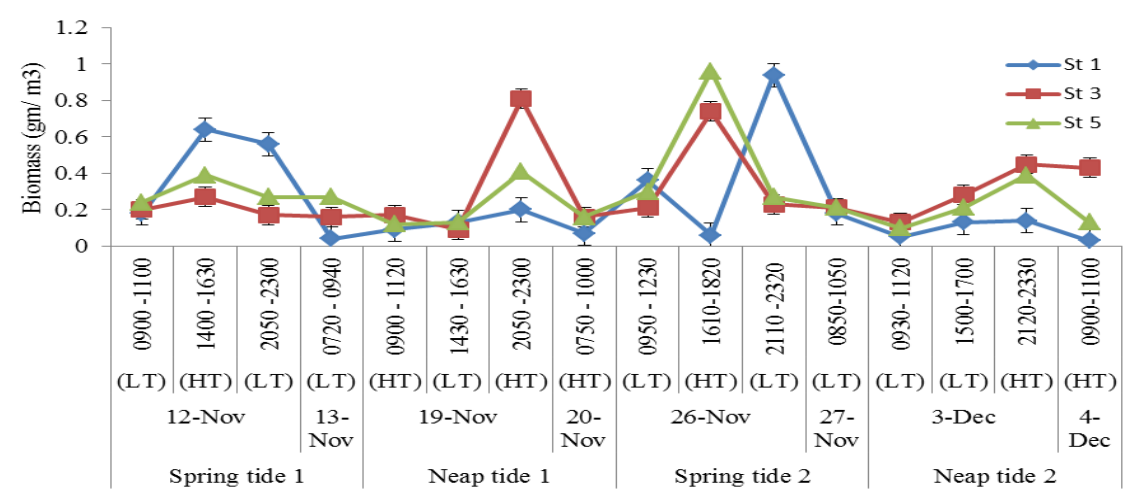

Fig. 8. Zooplankton biomass at all sampling stations in Merbok River estuary during 24 - hour observation

\section{Conclusions}

Water quality parameters (conductivity, transparency, TSS, BOD) positively influences zooplankton abundance and biomass during diurnal tidal variation. Tidal actions play a key role in zooplankton abundance. Higher zooplankton abundance and biomass are observed in high tide while lower abundance and biomass in low tide. It may be concluded that zooplankton abundance in Merbok estuary is regulated by physico-chemical parameters and tidal action.

\section{References}

Ali, M.; Al Yamani, F. and Polikarpov, I. 2011. The effect of tidal cycles on the community structure of plankton (with emphasis on copepods) at AFMED Marina in winter (a preliminary study). Crustaceana, 84(5-6):5-6.

APHA. 1991. Standard methods for the examination of water and waste water $\left(18^{\text {th }}\right.$ Ed. New York ed.): American Public Health Association Inc.

Bais, V. S. and Agarwal, N. C. 1995. Comparative study of the zooplanktonic spectrum in the Sagar lake and military engineering lake. Journal of Environmental Biology, 16 (1):27-32.

Bernard, J. Y. 1975. Estuarine water quality. Washington, D. C: The Conservation Foundation.

da Costa, K. G.; Pinheiro, P. R. S.; Melo, C. A. R.; de Oliveira, S. M. O.; Pereira, L. C. C. and da Costa, R. M. 2011. Effects of seasonality on zooplankton community dynamics in the macrotidal coastal zone of the Amazon region. J. Coastal Res. SI 64 (Proceedings of the $11^{\text {th }}$ International Coastal Symposium), 364-368.

Davies, O. A. and Ugwumba, O. A. 2013. Effects of tide on zooplankton community of a tributary of Upper Bonny Estuary, Niger Delta, Nigeria. International Journal of Scientific Research in Knowledge 1(9):325-342.

Ho, R. 2006. Handbook of univariate and multivariate data analysis and interpretation with SPSS. 372 p.

Krumme, U. and Liang, T. H. 2004. Tidal-induced changes in a copepod-dominated zooplankton community in a macrotidal mangrove channel in Northern Brazil. Zoological Studies, 43(2):404-414.

Postel, L.; Fock, H. and Hagen, W. 2000. In: Harris, R.; Wiebe, P.; Lenz, J.; Skjoldal, H.R. and Huntley, M. (Eds), ICES Zooplankton methodology manual, Chapter. 4. Biomass and abundance. Academic Press, London. pp. 83-192.

Reeve, M. R. 1975. The ecological significance of the zooplankton in the shallow sub-tropical waters of South Florida. In E. Cronin (Ed.), Estuarine research: Chemistry, Biology and the Estuarine system, 1. New York: Academic.

Reid, G. K. 1961. Ecology of inland waters and estuaries. New York: Van Nostrand Reinhold Company.

Robertson, A. I.; P. Dixon and P. A. Daniel. 1988. Zooplankton dynamics in mangrove and other near shore habitats in tropical Australia. Marine Ecological Progress Series, 43:139-150.

Strickland, J. D. H. and Parsons, T. R. 1972. A practical handbook of seawater analysis. Fisheries Research Board of Canada, Ottawa, 310 p.

Sun, X. H.; Sun, S.; Li, C. L. and Zhang, G. T. 2011. Seasonal and spatial variability in egg production, abundance and production of small copepods in and near Jiaozhou Bay, China. Journal of plankton research, 33(5):741-750.

Tebbutt, T. H. Y. 1998. Principles of water quality control $5^{\text {th }} E d$. London, Oxford: ButterworthHeinemann.

Villate, F. 1997. Tidal influence on zonation and occurrence of resident and temporary zooplankton in a shallow system (estuary of Mundaka, Bay of Biscay). Scientia Marina, 61: 173-188.

Wang, Z.; Thiebaut, E. and Dauvin, J. C. 1995. Shortterm variations of zooplankton in a megatidal estuary (Seine, eastern English Channel). Spatial and temporal scales of the ocean.Methods and problems. Paper presented at the Proc. of the $20^{\text {th }}$ Symp. 24-25 Nov., France, Paris.

Wetzel, R. G. and Likens, G. E. 2000. Limnological analyses: Springer. 